\title{
Käyttäjätieto uuden teknologian arvioinnissa ja kehittämisessä
}

\author{
Kim O. Kaustell ${ }^{1)}$, Tiina E.A. Mattila ${ }^{1)}$ ja Juha Suutarinen ${ }^{2)}$ \\ 1) MTT Taloustutkimus, Vakolantie 55,03400Vihti, etunimi.sukunimi@mtt.fi \\ 2)MTT Taloustutkimus, Luutnantintie 13,00410Helsinki,juha.suutarinen@mtt.fi
}

\section{Tiivistelmä}

Käyttäjätieto on tietoa esimerkiksi teknologisten ratkaisujen käyttäjistä ja käyttöympäristöistä sekä näiden välisestä vuorovaikutuksesta. Hyvän käytettävyyden kolmesta päätekijästä, vaikuttavuudesta, tehokkuudesta ja miellyttävyydestä, viimeisin on saanut vähiten huomiota tuotteiden suunnittelussa. Tämän tutkimuksen tavoitteena on rakentaa tutkimusmenetelmäkokonaisuus, jonka avulla voidaan tutkia liikkuvan työkoneen kuljettajan (käyttäjän) kuormittumista ja siihen vaikuttavia tekijöitä sekä käyttäjäkokemuksia.

Mittausjärjestelyssä käytettiin videoinnin lisäksi sykemittausta, jonka avulla pyrittiin määrittämään käyttäjäkokemusta sekä paikantamaan kuormitushuippuja työrupeamasta. Neljä koehenkilöä teki kuusi erilaista traktorin peruskäyttöön liittyvää tehtävää. Kaikki tehtäväsuoritukset videoitiin ja kunkin koehenkilön testitehtävien aikainen, sykevälivaihtelusta johdetun stressivektorin taso analysoitiin. Kuormittavuuden kriteerinä pidettiin stressivektorin arvoa, jonka ko. vektori ylitti vain $10 \%$ työajasta. Koehenkilöitä pyydettiin lisäksi arvioimaan eri tehtävien kuormittavuutta.

Kaikki koehenkilöt arvioivat pimeässä tehdyt tehtävät kuormittavammiksi kuin valoisalla tehdyt tehtävät. Mitattu ja arvioitu kuormittuminen eivät korreloineet, mikä voi johtua koejärjestelystä tai siitä, että oma kokemus ja sykevälivaihtelusta laskettu kuormitus eivät mittaa täysin samaa asiaa. Kuormitushuiput liittyivät tehdyissä kokeissa suureen ajonopeuteen sekä maantiellä että piha- ja peltoteillä. Peltotieltä maantielle kääntyminen sekä ajoneuvon kohtaaminen kapealla pihatiellä, samoin kuin pujotteluradan peruuttaminen pimeällä perävaunun kanssa oli mittausten mukaan kuormittavaa. Koehenkilöt mainitsivat kuormittumisen syiksi erityisesti traktorin heilunnan, huonon näkyvyyden taaksepäin ja sen, etteivät traktorin taustapeilit tai työvalot olleet/pysyneet oikein säädettyinä.

Tulosten mukaan näyttää siltä, että stressivektorin ja videotallennuksen sekä käyttäjiltä saadun palautteen avulla voidaan erottaa sekä lyhyitä, suuruusluokkaa 5..10s kestäviä, että pidempikestoisia kuormittavia työvaiheita ja kuormitustekijöitä. Saadut tulokset ovat kuitenkin alustavia ja niiden vahvistaminen vaatii useampia toistoja ja pidempiä mittausjaksoja. Tutkimus/mittausmenetelmää voidaan kehittää edelleen siten, että päästään mielenkiintoisella ja lisäarvoa tuottavalla tavalla analysoimaan kuljettajan kuormittumista ja käyttäjäkokemusta ja sitä kautta kehittämään käytössä ja suunnitteilla olevien koneiden ja laitteiden käytettävyyttä.

\section{Asiasanat}

Käyttäjätieto, käyttäjätutkimus, sykevälivaihtelu, kuormittavuus, traktori, kuljettaja, maatalous 


\section{Johdanto}

Käyttäjätieto on tietoa esimerkiksi teknologisten ratkaisujen käyttäjistä ja käyttöympäristöistä sekä näiden välisestä vuorovaikutuksesta. Todellisessa käyttöympäristössä ja todellisilta käyttäjiltä kerätystä käyttäjätiedosta sekä kyvystä tulkita ja hyödyntää tätä tietoa on tullut keskeinen kilpailutekijä. Hyvän käytettävyyden kolmesta päätekijästä, vaikuttavuudesta, tehokkuudesta ja miellyttävyydestä (ISO 9241-11 ), viimeisin on saanut vähiten huomiota tuotteiden suunnittelussa. Tuotekehityksessä ja työn suunnittelussa on kuitenkin välttämätöntä ymmärtää suoriutumista mittaavien tuloksellisuuden ja tehokkuuden kriteerien rinnalla miellyttävyyteen liittyviä tekijöitä, kuten tyytyväisyys ja käyttökokemus.

Pitkäaikaisessa käytössä esille tulevat käytettävyyspiirteet ovat merkityksellisiä myös koneiden markkinoinnin ja merkkiuskollisuuden kannalta. Ne luovat kuvaa koneen laadusta. Ymmärrys kuormittumista lisäävistä ja vähentävistä tekijöistä ohjaamoympäristössä on keskeistä, jotta työkokonaisuudesta voidaan luoda miellyttävä ja kuljettajan työtä helpottava ja tukeva. Maatalousteknologian alalla tehty käytettävyystutkimus (esim. Nurkka 2005 ja Nurkka \& Suomi 2006) on osoittanut, että laitteiden käyttöön liittyvät ongelmat ovat löydettävissä.

Maatilatalouden rakennemuutos on tuonut tullessaan mm. suuremmat käsiteltävät peltopinta-alat. Ajettavien työkoneiden ohjaamoissa ollaan entistä pidempiä aikoja ja työtä helpottamaan on kehitetty monenlaista, pääosin elektroniikkaan ja tietotekniikkaan liittyvää laitteistoa. Sopivilla avustavilla toiminnoilla sekä automatisoinnilla onkin mahdollista vähentää kuljettajan henkistä kuormittumista ja tehostaa työn tuottavuutta (Burman \& Löfgren 2007). Työn kuormittavuuteen liittyvät tekijät saavat tutkimusten mukaan suuren painoarvon hankintoihin liittyvissä päätöksentekoprosesseissa. Työolojen parantaminen ja työn määrän sekä fyysisen rasituksen vähentäminen vaikuttavat usein voimakkaana motivoivana tekijänä maatilan investoinneissa (esim. Latvala \& Suokannas 2005, Mattila \& Manninen 2006).

Tämän tutkimuksen tavoitteena on rakentaa tutkimusmenetelmäkokonaisuus, jonka avulla voidaan tutkia liikkuvan työkoneen kuljettajan (käyttäjän) kuormittumista ja siihen vaikuttavia tekijöitä sekä käyttäjäkokemuksia. Dey \& Mann (2006) ovat esittäneet, että kuljettajan kuormittumista pitäisi tutkia mm. sykevälivaihtelun avulla. Vuoden 2007 aikana on tutkittu ja kehitetty sydämen sykevälianalyysin ja videoinnin sekä näihin yhdistettyjen muiden havainnointi- ja haastattelumetodien yhdistelmää, jonka tarkoituksena on löytää ohjaamoympäristöstä ja -työstä kuljettajaa kuormittavia ja siten miellyttävyyteen vaikuttavia tekijöitä.

\section{Aineisto ja menetelmät}

Käytetty mittausjärjestely luotiin erityisesti liikkuvan työkoneen kuljettajan havainnoimiseen. Käyttäjätutkimuksessa usein käytetyn videoinnin lisäksi tehtiin sykemittauksia, joiden avulla pyrittiin määrittämään tiedostamatonta käyttäjäkokemusta sekä paikantamaan kuormitushuippuja työrupeamasta. Tällä menettelyllä voitaisiin kohdentaa videohavaintojen analyysiä nimenomaan kuormitusta aiheuttavien tekijöiden selvittämiseen. Laitteiston testaamiseksi koehenkilöillä teetettiin normaaleja traktoritöitä.

Mittausjärjestely esitestattiin yhden koehenkilön avulla. Sen jälkeen tehtäväsarjaa laajennettiin ja koe tehtiin vielä neljän koehenkilön avulla. Nämä neljä koehenkilöä olivat maatalousalan 3 . vuosikurssin AMK-opiskelijoita ja he tekivät kuusi erilaista ajotehtävää traktorilla. Tehtävät liittyivät traktorin peruskäyttöön:

1. Traktorilla ajo peltotiellä, piha-alueella ja maantiellä

2. Perävaunun kiinnitys traktoriin konekatoksesta, ajo peltotiellä ja maantiellä, pujottelu etuperin ja takaperin sekä perävaunun palautus konekatokseen

3. Ajo pellolla GPS-navigaattorin (Garmin 60CSx) avulla ennalta laadittua reittiä laitteen opastusnuolen mukaisesti. Reitti koostui kuudesta reittipisteestä kehämäisellä radalla.

4. Tyhjien kuormalavojen siirtely ja pinoaminen traktorin etunostolaitteeseen kiinnitetyn haarukan avulla

5. Tehtävä kaksi (traktori+perävaunu) toistettiin pimeässä

6. Tehtävä neljä (tyhjien kuormalavojen siirtely) toistettiin pimeässä

Tehtäväsuoritukset tallennettiin kolmen ohjaamoon kiinnitetyn kameran avulla videotallentimelle (Kodicom KSR304N). Koehenkilöillä oli tallentava sykepanta (Suunto SmartBelt) koko testipäivän sekä 
seuraavan yön ja aamupäivän. Sykepantaan taltioituneesta datasta tuotettiin Firstbeat Technologies Oy:n Hyvinvointianalyysi-ohjelman avulla (versio 2.2.0.9) stressiraportit ja koehenkilöiden absoluuttiset stressivektorit. Stressivektorin laskenta perustuu sykevälivaihteluun, jonka on useissa tutkimuksissa todettu korreloivan koehenkilön kuormituksen kanssa (Berntson \& Cacioppo 2003).

Kunkin koehenkilön testitehtävien aikainen stressivektorin taso analysoitiin. Jokaisen tehtävän osalta määritettiin stressivektorin taso, jonka arvo ylittyy $10 \%$ ajan kyseisen tehtävän mitatusta kokonaisajasta. Stressivektorin aikatiedon avulla tutkittiin videotallenteilta, minkälaisiin tehtäviin ja tilanteisiin em. menetelmällä stressivektorista löydetyt kuormitushuiput liittyivät. Koehenkilöiden kokemus tehtävien vaativuudesta ja siihen vaikuttavista tekijöistä kerättiin spontaaneista kommenteista testien aikana sekä lyhyellä ryhmähaastattelulla koeajoja seuraavana päivänä, jolloin myös esiteltiin alustavia raaka-analyysejä mittauksista.

\section{Tulokset ja tulosten tarkastelu}

Kerättyä aineistoa voidaan käyttää sekä tehtävien väliseen kuormitusvertailuun henkilöittäin että tehtävien sisältämien kuormitustekijöiden tarkasteluun. Koska sekä koettu kuormitus että sykevälivaihtelusta määritetty kuormitus perustuvat koehenkilöiden yksilöllisiin piirteisiin, ei eri koehenkilöiden tuloksia voi yhdistellä tehtävän vaativuuden arvioimiseksi.

Koehenkilöitä pyydettiin arvioimaan eri tehtävien kuormittavuutta tehtävien suorituksen jälkeisenä päivänä ennen kuin he saivat tietää alustavia tuloksia sykemittauksissa lasketuista kuormituksista. Taulukossa 1 on esitetty sekä mitatut että koehenkilöiden itse arvioimat tehtävien kuormittavuudet järjestysasteikolla. Mitatun kuormittavuuden kriteerinä pidettiin stressivektorin arvoa, jonka ko. vektori ylitti vain $10 \%$ työajasta.

Taulukko 1. Tehtävät järjestettyinä mitattujen ja koehenkilöiden itse arvioimien kuormittavuuksien mukaan kuormittavimmasta vähiten kuormittavaan. Pimeätehtävät 5 ja 6 on merkitty tummennetulla taustalla. Koehenkilöiltä 3 ja 4 puuttuu mittausarvoja.

\begin{tabular}{|c|c|c|c|c|c|c|c|c|}
\hline \multirow{2}{*}{$\begin{array}{l}\text { Kuormit- } \\
\text { tavuus }\end{array}$} & \multicolumn{2}{|c|}{ Koehenkilö 1} & \multicolumn{2}{|c|}{ Koehenkilö 2} & \multicolumn{2}{|c|}{ Koehenkilö 3} & \multicolumn{2}{|c|}{ Koehenkilö 4} \\
\hline & Mittaus & Arvio & Mittaus & Arvio & Mittaus & Arvio & Mittaus & Arvio \\
\hline Suurin & 5 & 6 & 2 & 6 & - & 6 & 2 & 6 \\
\hline & 2 & 4 & 1 & 5 & - & 5 & 4 & 5 \\
\hline & 6 & 3 & 4 & 4 & - & 4 & 1 & 4 \\
\hline & 1 & 5 & 6 & 2 & - & 3 & 3 & 2 \\
\hline$V$ & 4 & 2 & 5 & 3 & - & 2 & - & 3 \\
\hline Pienin & 3 & 1 & 3 & 1 & - & 1 & - & 1 \\
\hline
\end{tabular}

Tehtävät: $1 . \quad$ traktorilla ajo

2. traktorilla ajo perävaunun kanssa, peruutus ja pujottelu

3. GPS-reittiajo pellolla

4. kuormalavojen siirtely

5. kuten tehtävä 2., mutta pimeässä

6. kuten tehtävä 4., mutta pimeässä

Kaikki koehenkilöt arvioivat pimeässä tehdyt tehtävät 5 ja 6 kuormittavammiksi kuin valoisalla tehdyt tehtävät. Koehenkilö 1 arvioi kuitenkin lavojen siirron ja GPS-reittitehtävän vaikeammaksi kuin perävaunulla ajamisen pimeässä. Syyksi hän mainitsi tottumattomuutensa kuormalavojen käsittelyyn ja GPS-laitteen käyttämiseen.

Mitattu ja arvioitu kuormittuminen eivät korreloi niillä kahdella koehenkilöllä, joilta on sekä arvio- että mittaustieto käytettävissä. Toisilta koehenkilöiltä tätä vertailua ei voi tehdä. Korrelaation puute voi johtua siitä, että oma kokemus ja sykevälivaihtelusta laskettu kuormitus eivät mittaa samaa asiaa. Ero voi johtua myös koeasetelman tekijöistä, joita ovat mm. yksittäisten tehtävien lyhyys (alle 10 minuuttia) sekä se, että koehenkilöt mahdollisesti kokivat mittaustilanteen kilpailutilanteena, jossa oli ns. "näytön paikka". Koehenkilöt olivat tekemisissä toistensa kanssa tehtävien välillä ja koepäivän jälkeen, jolloin kollektiivinen arvio on voinut vaikuttaa subjektiiviseen arviointiin. 
Tarkkuutta vaativan lavojen siirtotyön vaikeuttaminen toistamalla työ pimeässä nosti selvästi koehenkilön 1 stressitasoa (Kuva 1). Kuormitusta kuvaava stressivektori oli lähes koko pimeässä suoritetun ajan suurempi kuin taso, joka ylitettiin valoisalla vastaavassa tehtävässä vain 10 \% työajasta. Koehenkilön mukaan lavojen lastaus oli vaikein työtehtävä, erityisesti pimeässä, koska työkokemus ko. työstä oli vähäinen. Stressivektorin huiput ajoittuvat erityistä tarkkaavaisuutta edellyttäviin työvaiheisiin, kuten lavahaarukan ajamiseen lavapinoon tai kuormauksen epäonnistumiseen.

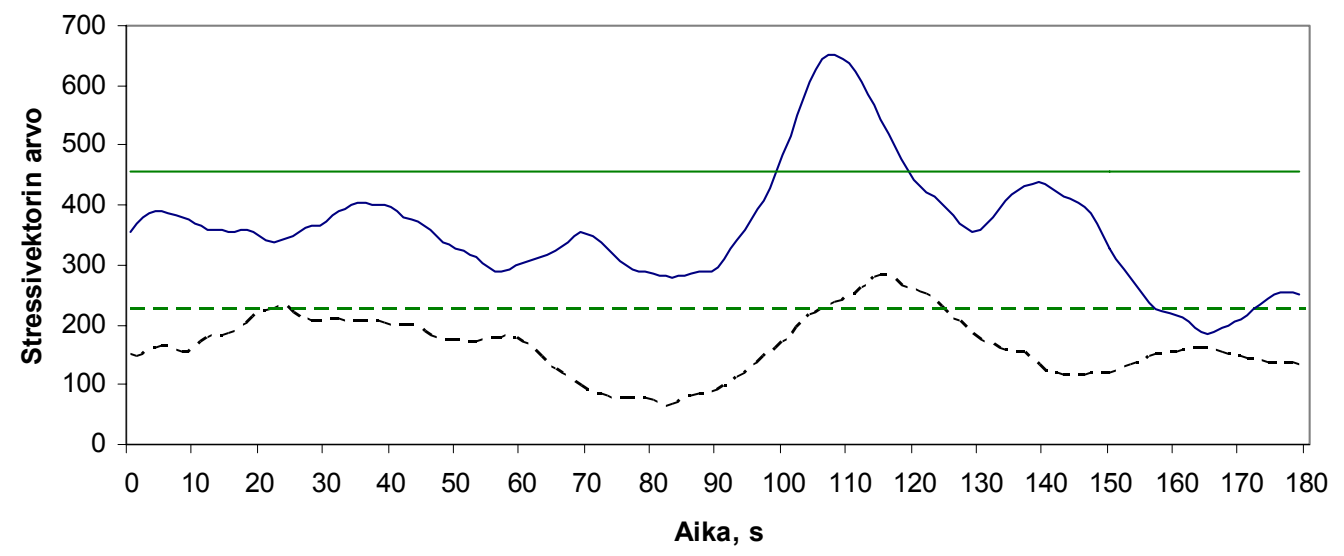

Kuva 1. Stressivektorikuvaajat kolmen minuutin jaksolta koehenkilön 1 siirrellessä kuormalavoja valoisaan aikaan (katkoviivakäyrä) ja pimeässä (yhtenäinen käyrä). Alempi, katkoviivalla piirretty suora kuvaa stressivektorin arvoa, joka ylittyi vain $10 \%$ tehtäväajasta valoisaan aikaan. Ylempi, yhtenäinen suora kuvaa vastaavaa arvoa pimeässä.

GPS-reittiajo oli sykemittausten mukaan vähiten kuormittava tehtävä, eikä siinä esiintynyt merkittäviä kuormitushuippuja. Koehenkilöt eivät kertomansa mukaan olleet tottuneet käyttämään ajo-opastinta tai muutakaan GPS-laitetta. Pelkällä traktorilla suoritetussa tehtävässä oli kuitenkin mahdollista keskittyä täysin laitteen antaman ajosuunnan pitämiseen ilman tarvetta tarkkailla samanaikaisesti esim. työkoneen työn jälkeä tai tarvetta säätää ajonopeutta tai työkoneen asetuksia.

Stressivektorihuippujen tarkastelussa kävi ilmi, että useat kuormitushuiput liittyivät tehdyissä kokeissa suureen ajonopeuteen sekä maantiellä että piha- ja peltoteillä. Nämä kuormitushuiput voivat johtua koejärjestelyn aiheuttamasta psyykkisestä kuormituksesta (koettu kilpailutilanne tai havainnoiduksi tuleminen) tai nopean ajon vaatimasta keskimääräistä korkeammasta valppaudesta. Epätasaisilla peltoteillä myös traktorin heilunta ja siihen liittyvä kohonnut ajohallintaan liittyvä kuormitus ovat voineet nostaa stressivektorin arvoa.

Erilaiset liikennetilanteet voivat olla kuormittavia. Peltotieltä maantielle kääntyminen sekä ajoneuvon kohtaaminen kapealla pihatiellä aiheuttivat kuormitushuippuja. Pujotteluradan peruuttaminen pimeällä perävaunun kanssa oli mittausten mukaan kuormittavaa. Koehenkilöt mainitsivat kuormittumisen syyksi erityisesti huonon näkyvyyden taaksepäin ja sen, etteivät traktorin taustapeilit olleet/pysyneet oikein säädettyinä.

Huono näkyvyys etukuormaajassa olleeseen kuormalavahaarukkaan vaikeutti trukkilavojen siirtoa. Koehenkilöt hakeutuivat ohjaamossa hyvin epämukaviin asentoihin nähdäkseen lavahaarukan asennon ja sijainnin suhteessa kuormattaviin lavoihin. Pimeys ja työvalojen riittämätön valoteho sekä huono suuntaus mainittiin erityisinä työtä vaikeuttavina tekijöinä.

Koska sykevälivaihteluun perustuva stressivektori on herkkä sekä fyysiselle että psyykkiselle kuormitukselle, näkyivät myös tehtävien aikaiset ohjaamosta poistumiset ja ohjaamon nousemiset lyhyinä kuormitushuippuina. Ohjaamosta poistumisen syynä olivat tehtävien vaihdon sekä esim. perävaunun kiinnityksen ja irrotuksen ohella mm. peilien säädöt ja työvalojen kohdistaminen. Myös huonosti kuormaushaarukkaan jääneiden lavojen asentoa käytiin korjaamassa.

Tulosten mukaan näyttää siltä, että stressivektorin ja videotallennuksen avulla voidaan erottaa sekä lyhyitä, suuruusluokkaa 5..10s kestäviä, että pidempikestoisia kuormittavia vaiheita ja kuormitustekijöitä. Saadut tulokset ovat kuitenkin alustavia ja niiden vahvistaminen vaatii useampia toistoja ja pidempiä mittausjaksoja. Näiden tulosten perusteella ei voida vielä varmuudella sanoa, että stressitason nousu liittyy tiettyyn työtehtävään. Myös muut tekijät kuin olosuhteet ja tehtävän psyykkinen kuormitus ovat voineet 
vaikuttaa tulokseen.

Mittausjärjestelmää on myös edelleen kehitettävä. Sykedata oli paikoin katkonaista johtuen ongelmista sykevöiden paristo- ja elektrodikontakteissa. Videotallenninjärjestelmän jännite laski tallennuksen aikana liian alas, mistä johtuen kahden kameran videosignaalin taso oli ajoittain liian alhainen ja videotallentimen toiminnassa oli häiriöitä. Järjestelmä käytti ulkoisena jännitelähteenä traktorin tupakansytytinliitäntää, jonka tuottama jännite ei riittänyt järjestelmälle sen vara-akusta huolimatta.

Vaikka sykedatan tulkinnassa on epävarmuustekijöitä, niin hyvinvointianalyysin tulos toimii kuitenkin hyvänä pohjana keskustelulle ja pohdinnalle, jossa voidaan saada esiin kuljettajan kokemuksia työstään ja sen kuormitustekijöistä.

\section{Johtopäätökset}

Koska kyseessä oli ensimmäinen kenttäolosuhteissa tehty mittaus prototyyppilaitteistolla, on mittausjärjestelyn tuottamia tuloksia pidettävä vain suuntaa-antavina. Mittausjärjestelyllä pystyttiin kuitenkin löytämään eroja kuljettajien kuormittumistasossa eri työtehtävien ja olosuhteiden (valoisa/pimeä) välillä. Yksittäisistä työtehtävistä pystyttiin erottamaan työvaiheita ja kontekstitekijöitä, jotka vaikuttavat kuljettajan kuormittumiseen ja sitä kautta työn miellyttävyyteen.

Tutkimus/mittausmenetelmää voidaan kehittää edelleen siten, että päästään mielenkiintoisella ja lisäarvoa tuottavalla tavalla analysoimaan kuljettajan kuormittumista ja käyttäjäkokemusta ja sitä kautta kehittämään käytössä ja suunnitteilla olevien koneiden ja laitteiden käytettävyyttä.

\section{Kirjallisuus}

Berntson G. G. \& Cacioppo J. T. 2003. Heart Rate Variability: Stress and Psychiatric Conditions. University of Chicago. http://psychology.uchicago.edu/people/faculty/cacioppo/jtcreprints/bc04.pdf (24.11.2007)

Burman, L. \& Löfgren, B. 2007. Human-machine interaction improvements of forest machines. Nordic Ergonomics Society 39th Annual Conference Oct 1-3, 2007, Lysekil, Sweden.

Dey, A.K. \& Mann, D.D. 2006. Workload associated with operation of an agricultural sprayer. Contemporary Ergonomics. Bust, P.D. (editor). Proceedings of the Annual Conference of the Ergonomics Society, Cambridge, UK. $616-620 \mathrm{~s}$

ISO 9241-11 1998. Näyttöpäätteillä tehtävän toimistotyön ergonomiset vaatimukset. Osa 11: Käytettävyyden määrittely ja arviointi.

Latvala, T. \& Suokannas, A. 2005. Automaattisen lypsyjärjestelmän käyttöönotto: kannattavuus ja hankintaan vaikuttavat tekijät. Pellervon taloudellisen tutkimuslaitoksen raportteja n:o $192.85 \mathrm{~s}$.

Mattila, T. \& Manninen, M. 2006 Investointi on vaihe vaiheelta etenevää ongelmanratkaisua. Työtehoseuran maataloustiedote 5 (590) $8 \mathrm{~s}$.

Nurkka, P. 2005. Study in usability evaluation in the field of agricultural engineering. In: (toim.) Coleen Heemskerk and Mari Engvall. Book of Abstracts 5 ECPA - 2 ECPLF. 218-219 s.

Nurkka, P. \& Suomi, P. 2006. Käytettävyystutkimus maatalousteknologiassa. Case: kuljettajan tilannetietoisuus. In: Toim. Anneli Hopponen. Maataloustieteen Päivät 2006, 11.-12.1.2006 Viikki, Helsinki [:esitelmät ja posterit]. Suomen maataloustieteellisen seuran tiedote $21: 7 \mathrm{~s}$. 